\title{
PENERAPAN PENDEKATAN KONTEKSTUAL TERHADAP KEMAMPUAN PEMAHAMAN DAN KOMUNIKASI MATEMATIS SISWA SMP
}

\author{
Asep Ikin Sugandi' , Martin Benard ${ }^{2}$ \\ 1,2 Program Studi Pendidikan Matematika, Fakultas Pendidikan Matematika \\ dan Sains, IKIP Siliwangi Jl. Terusan Jenderal Sudirman No. 3, Cimahi, \\ Indonesia
}

E-mail: asepikinsugandi@gmail.com

\begin{abstract}
ABSTRAK
Tujuan dalam penelitian ini adalah untuk meneleaah perbandingan kemampuan pemahaman dan komunikasi matematis siswa antara yang pembelajarnya menggunakan pendekatan konstekstual dengan pembelajaran biasa. Populasi dalam penelitian ini adalah seluruh siswa SMP yang berkemampuan sedang yang berada dikota Cimahi, sedangkan sampelnya dipilih dua kelas yang berjumlah 56 orang dari satu SMP di kota Cimahi yang berkemampuan sedang. Instrumen pada penelitian ini berupa tes berbentuk soal uraian untuk tes kemampuan pemahaman dan komunikasi matematis. Instrumen yang digunakan sudah memenuhi soal yang baik berdasarkan validitas, reliabilitas, daya pembeda dan indeks kesukaran. Berdasarkan perhitungan menggunakan SPSS 18 didapat hasil sebagai berikut (1) pencapaian dan peningkatan kemampuan pemahaman matematik yang pembelajarnya menggunakan pendekatan konstekstual lebih baik dibandingkan pembelajaran biasa. (2) pencapaian dan peningkatan kemampuan komunikasi matematis siswa yang pembelajarannya menggunakan pendekatan konstekstual lebih baik dibandingkan pembelajaran biasa.
\end{abstract}

Kata kunci: Pemahaman, Komunikasi, Kontekstual

\begin{abstract}
The purpose of this study was to compare the students' mathematical understanding and communication skills between the learner using the contextual approach with ordinary learning. The population in this study were all medium-skilled junior high school students who were in the city of Cimahi, while the sample was selected two classes of 56 people from a junior high school in Cimahi city that is capable. Instruments in this study form of test in the form of a description of the test for the ability of understanding and mathematical communication. The instruments used have met a good question based on validity, reliability, distinguishing power and difficulty index. Based on the calculation using SPSS 18 obtained the following results (1) achievement and improvement of the ability of mathematical understanding of the learner using a contextual approach is better than ordinary learning. (2) the achievement and improvement of mathematical communication ability of students whose learning using a contextual approach is better than ordinary learning).
\end{abstract}

Keywords: Keywords: Understanding, Communication, Contextual 


\section{PENDAHULUAN}

Kemampuan pemahaman dan komunikasi matematis merupakan dua kemampuan yang perlu diakuasai oleh siswa. Hal ini sejalan dengan maksud pembelajaran matematika yang tercantum dalam KTSP 2006 dan pada kurikulum 2013 (Hendriana dan Sumarmo, 2014) antara lain : memahami pengetahuan matematika, menjelaskan keterkaiatan antar pengetahuan dan mengaplikasikan pengetahuan atau logaritma, secara akurat, luwes dan efisien,) mengkomunikasikan suatu ide atau gagasan dengan lambang, (tabel), simbolis informasi (diagram), atau sarana lain dalam memberi penjelasan suatu situasi atau masalah.

Kemampuan pemahaman merupakan suatu kemampuan yang perlu dikuasai dalam pembelajaran matematika, mempunyai arti bahwa konsep-konsep matematika tidak hanya berupa hapalan saja, namun bisa diserap kedalam pemikiran siswa, sehingga siswa dapat mengaplikasikan konsep-konep tersebut dalam situasi dan keadaan yang lainnya Pemahaman juga merupakan salah satu tujuan dari setiap materi yang akan diajarkan oleh guru, karena guru yang membimbing siswa dalam mencapai konsep tersebut.

Berdasarkan gagasan para ahli (Sumarmo, 2014) mengemukakan terdapat dua bentuk pemahaman matematik, yaitu pemahaman tahap rendah meliputi pemahaman mekanikal, induktif, komputasional dan intrumental cirinya berupa mengingat, menggunakan rumus secara rutin dan menghitung secara sederhana (serupa) dan yang selanjutnya pemahaman matematik tahap tinggi yang beupa pemahaman, intuitif, rasional, fungsional dan pemahaman relasional. Adapun karakteristinya sebagai berikut mampu menghubungkan suatu konsep dengan konsep yang lainnya dan melakaukan perhitungan secara sadar, serta mampu membuktikan kebenaran rumus teorema. Atau rumus.

Disamping kemampuan pemahaman ada juga kemampuan yang perlu dikembangkan oleh siswa. Kemampuan itu adalah kemampuan komunikasi. Kemampuan komunikasi penting untuk dikembangkan karena kemampuan komunikasi dapat membantu siswa memahami masalah-masalah matematika yang disajikan dan mengemukakan gagasan-gagasan penyelesaian dan persoalan tersebut, serta memberikan argumen atau ide yang diutarakannya. Lebih lanjut Soedjadi, 2000) menyatakan bahwa indikasi utama matematika adalah penggunaan simbol-simbol dalam menunjukkan sesuatu , misalnya menunjukkan suatu konsep, fakta, operasi , prinsip/aturan. atapun operasi.

Adapun indikator kemampuaan komunikasi siswa menurut Sumarmo (Hendriana dan Sumarmo, 2014) antara lain :

a. Melukiskan dan merepresentasikan benda dan gambar nyata serta diagram dalam bentuk gagasan dan simbol matematika.

b. Menjelaskan gagasan, keadaan dan hubungan matematik, secara tertulis dan lisan menggunakan benda dan gambar nyata, grafik dan ekspresi aljabar

c. Menyatakan peristiwa sehariharidalam bahasa atau simbol matematikaatau menyususn model matematika suatu peristiwa

d. Mendengarkan, berdiskusi dan menulis tentang matematik

e. Menyatakan ulang uraian suatu paragaraf matematika dengan bahasa sendiri

Salah satu pendekatan yang diperkirakan dapat meningkatkan kemampuan pemahaman dan komunikasi matematik adalah pendekatan kontekstual. Pembelajaran menggunakan pendekatan 
Penerapan Pendekatan Kontekstual Terhadap Kemampuan Pemahaman Dan Komunikasi Matematis Siswa SMP

konstektual adalah konsep belajar yang berupaya menyambungkan antara konsep materi yang dipelajarinya dengan kehidupan nyata siswa dan mendorong siswa membuat relasi antara pengetahuan yang sudajh dimiliki dengan aplikasi dalam kehidupan sehari-hari dengan mengimplikasikan tujuh komponen efektif. Ada tujuh karakteristik utama pembelajaran konstektual, yaitu (1) kontruktivisme, (2) bertanya, (3) inkuiri, (4) masyarakat belajar, (5) pemodelan, (6) Refleksi dan (7) Pemilaian autentik.

Beberapa studi antara lain Bernard (2015) dan Jayadipura (2014), Sinurat (2014) Suheri (2014) Sunendar, melaporkan bahwa pembelajaran konstekstual lebih baik dibandingkan dengan pendekatan konvensional dalam meningkatkan beragam kemampuan matematik. Selain itu, beberapa hasil penelitian terdahulu di antaranya:, Hendriana(2009), Rohaeti (2008) menyimpulkan bahwa hasil kemampuan pemahaman siswa yang memperoleh pendekatan inovastif lebih baik dibandingkan yang pembelajarannya yang menggunakan pendekatan biasa. Disamping itu hasil penelitian antara lain (Mudrikah, 2013, Yonandi, 2010) menyatakan bahwa kemampuan komunikasi siswa yang memperoleh pembelajaran dengan beraneka ragam pendekatan dan model inovatif lebih baik dari pada pendekatan konvensional. Uraian tentang pembelajaran serta temuan sejumlah studi yang telah diutarakan lebih menguatkan prediksi peneliti bahwa pembelajaran menggunkan pendekatan kontekstual akan memfasilitasi berkembangnya kemampuan komunikasi dan pemahaman.

Adapun tujuan studi ini adalah menelaah perbandingan pencapaian dan peningkatan kemampuan pemahaman dan komunikasi matematis antara yang pembelajarannya mengunakan pendekatan kontekstual dengan yang menggunakan biasa, sedangkan manfaat dalam studi ini mencari alternatif pendekatan yang dapat diterapkan dalam pembelajaran untuk memperkaya khazanah pendekatan yang sudah ada dalam pendidikan matematika dalam rangka meningkatkan kemampuan berpikir tingkat tinggi.

\section{METODE PENELITIAN}

Metode yang digunakan dalam penelitian ini adalah metode eksperimen dengan pengambilan sampel secara acak. Dalam penelitian ini diperlukan dua kelompok, pertama adalah kelompok eksperimen yang diberi perlakuan berupa pembelajaran menggunakan pendekatan kontekstual dan yang kedua kelompok kontrol, yang diberi pembelajaran biasa yaitu pembelajaran yang sehari-hari dilakukan di sekolah. Sebelum dan sesudah perlakuan kedua kelompok diberi tes. Berdasarkan uraian di atas maka desain penelitiannya sebagai berikut :

$$
\begin{array}{llll}
\text { A : } & \text { O } & \text { X } & \text { O } \\
\text { A : } & \text { O } & & \text { O }
\end{array}
$$

Keterangan :

$$
\begin{aligned}
& \text { A = Pengambilan sampel secara acak } \\
& \text { kelas } \\
& \mathrm{O}=\text { Tes awal dan tes akhir } \\
& \mathrm{X} \quad=\text { Pemberian perlakuan berupa } \\
& \text { pembelajaran kontekstual. }
\end{aligned}
$$

Populasi dalam penelitaian ini adalah seluruh siswa kelas VIII siswa SMP Negeri se-kota Cimahi,sedangkan sampelnya dipilih dua kelas VIII dari salah satu SMP Negeri di Kota Cimahi. Instrumen yang digunakan pada penelitian ini adalah dua perangkat tes berbentuk soal uraian, satu soal digunakan untuk mengukur kemampuan pemahaman matematis dan satu set soal untuk mengukur kemampuan komunikasi matematis.

Prosedur penelitian terdiri dari dari 1) Tahap Persiapan, 2) Tahap Pelaksanaan dan 3) Tahap Evaluasi. Pada tahap persiapan, sebelum penelitian ini dilaksanakan terlebih dahulu diadakan 
persiapan-persiapan yang dipandang perlu, antara lain : melakukan studi kepustakaan mengenai kemampuan pemahaman dan komunikasi matematis dan pendekatan kontekstual, membuat rancangan pembelajaran kemampuan pemahaman dan komunikasi matematis dengan menggunakan model pendekatan kontekstual, maupun menggunakan pendetatan biasa. Setelah persiapan dianggap cukup, dilanjutkan pemilihan sampel dan dilanjutkan dengan penyusunan instrumen penelitian, melakukan uji coba coba instrumen serta merevisi instrumen tersebut agar dapat digunakan dalam penelitian.

Selanjutnya langkah pelaksanaan, dalam langkah ini, dimulai dengan memberi tes awal untuk mengukur kehomogenan kemampuan awal siswa pada awal penelitian. Sebelum pelaksanaan pembelajaran menggunakan pendekatan kontekstual di kelas eksperimen, maka diadakan sosialisasi dengan memberikan penjelasan mengenai aturan-aturan yang diterapkan dalam pembelajaran menggunakan pendekatan kontekstual. Selanjutnya diadakan latihan atau menguji coba pembelajaran tersebut dan sekaligus digunakan untuk pembentukan kelompok. Dalam penelitian ini penulis berperan sebagai guru pengajar yang memberikan materi dan sekaligus tugas kepada siswa, dengan pertimbangan untuk mengurangi bias karena perbedaan perlakuan pada masing-masing kelas. Pelaksanaan pembelajaran didua kelas dilaksanakan sesuai dengan jadwal yang ada di SMP (Cimahi) yaitu 5 jam pelajaran $(5 \times 40$ menit) untuk setiap minggu. Sebagai langkah terakhir, yaitu pemberian tes akhir kepada kedua kelompok, kemudian dihitung N-gain peningkatannya.

Berikut ini ditampilkan beberapa contoh tes kemampuan pemahaman, kemampuan komunikasi matematik matematis yang digunakan dalam studi ini

\section{HASIL DAN PEMBAHASAN}

Dari hasil perhitungan data dengan menggunkan SPSS 18 didapat hasil penelitian sebagai berikut :

Tabel 1 . Kemampuan Pemahaman, dan Komunikas Matematis

\begin{tabular}{|c|c|c|c|c|c|c|c|c|}
\hline \multirow[b]{2}{*}{ Variabel } & \multirow[b]{2}{*}{ Statistik } & \multicolumn{3}{|c|}{ Pembelajaran Kontekstual } & \multicolumn{3}{|c|}{ Pembelajaran Konvensional } & \multirow[t]{2}{*}{ SMI } \\
\hline & & Pre tes & Pos Tes & N-Gain & Pre tes & Pos Tes & N-Gain & \\
\hline \multirow{4}{*}{ Pemahaman } & Rerata & 3,68 & 13,86 & 0,62 & 3,29 & 11,93 & 0,49 & \multirow{4}{*}{20} \\
\hline & \% SMI & 18,46 & 68 & & 16,45 & 59,65 & & \\
\hline & SB & 1,09 & 2,10 & 0,12 & 0,93 & 2,39 & 0,18 & \\
\hline & $\mathrm{N}$ & 28 & 28 & 28 & 28 & 28 & 28 & \\
\hline \multirow{4}{*}{ Komunikasi } & Rerata & 3,61 & 9,04 & 0,44 & 3,36 & 7,59 & 0,44 & \multirow{4}{*}{16} \\
\hline & \%SMI & 22,56 & 56,5 & & 21 & 47,25 & & \\
\hline & SB & 1,39 & 1,79 & 0,018 & 1,06 & 2,59 & 0,19 & \\
\hline & $\mathrm{N}$ & 28 & 28 & 28 & 28 & 28 & 28 & \\
\hline
\end{tabular}


Penerapan Pendekatan Kontekstual Terhadap Kemampuan Pemahaman Dan Komunikasi Matematis Siswa SMP

Setelah dilakukan pengujian normalitas terhadap pre tes, pos tes dan $\mathrm{N}$-gain dengan menggunakan uji Kolmogorov Smirnov ternyata sebaran data untuk kemampuan pemahaman dan komunikasi matematis tidak berdistribusi normal. Untuk menguji perbedaaan dua rata-rata kemampuan pemahaman dan komunikasi matematis maka digunakan uji Mann-Whitney. Hipotesis yang akan diuji untuk hasil pos tes kemampuan pemahaman adalah sebagai berikut :

Ho : Tidak terdapat perbedaan pencapaian kemampuan pemahaman matematis siswa antara yang pembelajarannya menggunakan konteks-tual dengan biasa

$\mathrm{H}_{1}$ : Pencapaian kemampuan pemahaman matematis siswa lebih baik dari pada yang pembelajarannya menggunakan pendekatan kontekstual lebih baik daripada pendekatan biasa

Adapun hipotesis untuk menguji N-gain diformulasikan sebagai berikut :

Ho : Tidak terdapat perbedaan peningkatan kemampuan pemahaman matematis siswa SMP antara yang pembelajarannya menggunakan pendekatan kontekstual lebih baik daripada pendekatan biasa

$\mathrm{H}_{1}$ : Peningkatan kemampuan pemahaman matematis siswa lebih baik dari pada yang pembelajarannya menggunakan pendekatan kontekstual lebih baik daripada pendekatan biasa. Adapun hasil pengujian dengan menggunakan Mann Whitney, kami tampilkan pada Tabel 2 berikut ini :

Tabel 2. Uji Pos Tes dan N-Gain

Kemampuan Pemahaman Matematis

\begin{tabular}{ccccc}
\hline \multirow{2}{*}{$\begin{array}{c}\text { Perhitung } \\
\text { an }\end{array}$} & \multirow{2}{*}{ Kelas } & \multicolumn{2}{c}{ Uji Mann - } & \multirow{2}{*}{ Whitney } \\
\cline { 3 - 4 } & & $\mathrm{N}$ & $\begin{array}{c}\text { Signifik } \\
\text { an }\end{array}$ & \\
\hline Pos Tes & $\begin{array}{c}\text { Eksperim } \\
\text { en }\end{array}$ & 2 & & \\
& & 8 & 0,02 & Ho \\
\hline
\end{tabular}

\begin{tabular}{ccccc}
\hline & Kontrol & 2 & & Ditola \\
& & 8 & & $\mathrm{k}$ \\
\hline \multirow{2}{*}{ N-Gain } & Eksperim & 2 & & \\
& en & 8 & 0,006 & Ho \\
& Kontrol & 2 & & Ditola \\
& & 8 & & $\mathrm{k}$ \\
\hline
\end{tabular}

Dari Tabel 2 di atas, didapat temuan sebagai berikut: pencapaian dan peningkatan kemampuan siswa dalam pemahaman matematis yang belajarnya menggunakan kontekstual lebih baik dibandingkan konvensional. Pencapaian dan peningkatan untuk kedua kelas baik kontekstual maupun konvensional berada pada kategori sedang (untuk kelas kontekstual 68\% dari SMI), sedangkan konvensional 59,65\% dari SMI). Temuan ini sejalan dengan penelitian yang dilakukan oleh Hendriana (2009), Rohaeti (2004), Martunis,et.al (2014), Mulyati (2016) Rosmayadi (2018) hasil penelitiannya menyatakan bahwa penggunaan pendekatan inovatif lebih efektif dalam meningkatkan kemampuan pemahaman matematis siswa. Hendriana mengadakan penelitian di SMA menggunakan pendekatan Methapora Thingking. Rohaeti melakukan penelitian pada siswa SMP menggunakan pendekatan Improve, sedangkan Martunis mengadakan penelitian pada siswa SMA menggunakan pendekatan generatif, Mulyati melakukan penelitian pada siswa SMA mnengunakan Strategi Preview-Question-Read-ReflectRecite-Revie Rosmayadi melakukan penelitian pada siswa SMP menggunakan strategi pembelajaran Group to Gruop Exchange Berpendekatan Kontekstual.

Adapun alasan penerapan pendekatan Kontekstual dapat meningkatkan kemampuan pemahaman, karena menurut definisi pendekatan kontekstual adalah pendekatan yang mengaitkan konsep-konsep pembelajaran dengan kehidupan realn/yata siswa, Hal ini menyebabkan pengajaran matematika yang bersifat abstrak dapat menjadi konkrit, sehingga pemahaman siswa meningkat.

Untuk selanjutnya dibahas mengenai uji perbedaan dua rata-rata dan $\mathrm{N}$-Gain untuk 
kemampuan komunikasi matematis. Adapun hipotesis yang akan diuji sebagai berikut :

Ho : Tidak terdapat perbedaan pencapaian kemampuan komunikasi matematis siswa SMP antara yang pembelajarannya menggunakan pendeka- tan kontekstual dengan penbelajaran biasa

$\mathrm{H}_{1} \quad$ : Pencapaian kemampuan komunikasi matematis siswa SMP lebih baikdari pada yang pembelajarannya menggunakan pendekatan kontekstual lebih baik daripada pendekatan biasa

Adapun hipotesis untuk menguji N-gain diformulasikan sebagai berikut :

Ho : Tidak terdapat perbedaan peningkatan kemampuan pemahaman matematis siswa SMP antara yang pembelajarannya menggunakan pendekaatan kontekstual lebih baik daripada pendekatan biasa

$\mathrm{H}_{1}$ : Peningkatan kemampuan pemahaman matematis siswa SMP lebih baik dari pada yang pembelajarannya menggunakan pendekatan kontekstual lebih baik daripada pendekatan biasa. Adapun hasil pengujian dengan menggunakan Mann Whitney, kami tampilkan pada Tabel 3 berikut ini :

Tabel 3. Uji Pos Tes dan N-Gain Kemampuan Pemahaman Matematis

\begin{tabular}{ccccc}
\hline \multirow{2}{*}{$\begin{array}{c}\text { Perhitung } \\
\text { an }\end{array}$} & Kelas & \multicolumn{2}{c}{ Uji Mann - } & \\
\cline { 2 - 3 } & & $\mathrm{N}$ & $\begin{array}{c}\text { Signitney } \\
\text { an }\end{array}$ & \\
\hline Pos Tes & Eksperim & 2 & & \\
& en & 8 & 0,009 & Ho \\
& Kontrol & 2 & & Ditola \\
& & 8 & & $\mathrm{k}$ \\
\hline N-Gain & Eksperim & 2 & & \\
& en & 8 & 0,006 & Ho \\
& Kontrol & 2 & & Ditola \\
& & 8 & & $\mathrm{k}$ \\
\hline
\end{tabular}

Dari Tabel 3 di atas, didapat temuan sebagai berikut : Pencapaian dan peningkatan kemampuan dalam komunikasi matematik yang belajarnya menggunakan Pendekatan kontekstual lebih baik dibandingkan yang menggunakan pendekatan konvensional. Pencapaian baik untuk kelas kontekstual dan konvensional sama-sama pada kategori kurang/rendah (kelas kontekstual 56,5\% dari SMI, sedangkan untuk kelas konvensional 47,25\% .SMI. Untuk peningkatan kedua kelas sama-sama mencapai kategori sedang. Hal ini sesuai dengan penelitian Permana (2010), Yonandi (2010), Mundrikah (2013), Martunis,et.al (2014) Martunis,et.al (2014), Benard (2015) yang menyatakan bahwa kemampuan komunikasi matematik siswa yang belajarnya menggunakan pendekatan inovasi lebih baik daripada pembelajaran biasa. Permana melakukan penelitian di SMA menggunakan Model-Eliciting, Activities, Yonandi melakukan penelitian pada siswa SMA menggunakan pendekatan Konstektual berbantuan komputer, Mundrikah melakukan penelitian pada siswa SMA menggunakan pembelajaran berbasis masalah dengan berbantuan komputer, Martunis mengadakan penelitian pada siswa SMA menggunakan pendekatan generatif, Benard mengadakan penelitian di SMK menggunakan pendekatan Kontekstual dengan melalui Cs. 4.

Adapun alasan penerapan pendekatan Kontekstual dapat meningkatkan kemampuan komunikasi matematis karena ada kesamaan pada indikator omunikasi matematis dengan karakteristik pendekatan, misalnya indikator dalam dalam kemampuan komunikasi, Melukiskan dan merepresentasikan benda dan gambar nyata serta diagram dalam bentuk gagasan dan simbol atau simbol matematika., Menjelaskan gagasan, keadaan dan hubungan matematik, secara tertulis dan lisan dengan menggunakan benda dan gambar nyata, grafik dan ekspresi aljabar, menyatakan peristiwa sehari-hari dalam bahasa atau simbol matematikaatau menyususn model matematika 
Penerapan Pendekatan Kontekstual Terhadap Kemampuan Pemahaman Dan Komunikasi Matematis Siswa SMP

suatu peristiwa berkaitan erat dengan karakteristik kontekstual misalnya pemodelan, inkuiri, kontrktivisme dan masyarakat belajar, dengan erat kaitan indikator kemampuan komunikasi dengan karakteristik Kontekstual mengakibatkan meningkatnya kemampuan pemahaman.

\section{KESIMPULAN}

Penelitian ini memberikan kesimpulan sebagai berikut : Pencapaian dan peningkatan kemampuan siswa dalam pemahaman, komunikasi matematis siswa yang pembelajarannya menggunakan pendekatan kontekstual lebih baik dibandingkan pembelajaran konvensional. Kemampuan pemahaman matematis baik pada pada kelas kontekstual maupun konvensional berada pada kategori sedang, namun pada kemampuan komunikasi kedua kelas berada pada kategori kurang.

Berdasarkan kesimpulan yang telah diutarakan maka saran dalam penelitian ini adalah pembelajaran Kontekstual dapat digunakan sebagai alternatif yang dapat diplih untuk model pembelajaran dalam matematika terutama untuk topik-topik terpilih dalam matematika.

\section{DAFTAR PUSTAKA}

Bernard, M. (2015). Meningkatkan Kemampuan Komunikasi dan Penalaran Serta Disposisi Matematiks Siswa SMK dengan Pendekatan Kontekstual melalui Flash Cs.4. Infinity Jurnal Ilmiah Program Studi Matematika STKIP Siliwangi Bandung, 4(2),

Hendriana, H. dan Sumarmo, U. (2014). Penilaian Pembelajaran Matematika. Bandung : PT. Refika Aditama

Hendriana, H. (2009). Pembelajaran dengan pendekatan methaporical thinking untuk meningkatkan kemampuan pemahaman matematik, komunikasi matematik dan kepercayaan diri siswa SMP. Disertasi. Bandung: Universitas Pendidikan Indonesia.

Jayadipura, Y. (2014). Mengembangkan Kemampuan Berpikir Kritis dan Kreatif serta Kemandirian Belajar Siswa SMA melalui Pembelajaran Kontekstual. Tesis pada Program Pascasarjana STKIP

Siliwangi Bandung : Tidak dipublikasikan.

Martunis , et.al. (2014). Meningkatkan Kemampuan Pemahaman dan Komunikasi Matematis Siswa Sekolah Menengah Atas melalui Model Pembelajaran Generatif. Jurnal Didaktik Matematika, 1(2),

Mudrikah, A. (2013). Pembelajaran Berbasis Masalah Berbantuan Komputer untuk Meningkatkan Kemampuan Komunikasi dan Pemecahan Masalah dan Disposisi Matematik Siswa SMA. Disertasi. Bandung: Universitas Pendidikan Indonesia.

Mulyati. (2016). Peningkatan Kemampuan Pemahaman dan Representasi Matematis Siswa SMA melalui Strategi PreviewQuestion-Read-Reflect-Recite-Review. Jurnal Analisa, 2(3),

Permana, Y. (2010). Kemampuan Pemahaman dan Komunikasi serta Disposisi Matematik terhadap Siswa SMA melalui Model-Eliciting, Activities. Disertasi pada Sekolah Pascasarjana Universitas Pendidikan : Tidak dipublikasikan.

Rohaeti, E. E. (2004). Pembelajaran matematika dengan Menggunakan Metode Improve untuk Meningkatkan Pmahamandan Kemampuan Komunikasi 
Matematik Siswa SLTP. Tesis.Bandung: Universitas Pendidikan Indonesia.

Rosmayadi, et.al. (2018). Pemahaman Konsep Matematis siswa dengan Strategi Pembelajaran Group to Gruop Exchange Berpendekatan kontekstual. Jurnal Penelitian dan Pembelajaran Matematika, 11 (1),

Sinurat, R. (2014). Meningkatkan Kemampuan Berpikir Krstis dan Kreatif serta Disposisi Matematik Siswa SMA melalui Pembelajaran Kontektual. Tesis pada Pascasarjana STKIP Siliwangi Bandung : Tidak diterbitkan.

Soedjadi,R. (2000). Kiat Pendidikan Matematika di Indonesia. Jakarta :
Direktorat Jenderal Pendidikan Tinggi Departemen Pendidikan Nasional.

Suheri (2014). Kemampuan Berpikir Kreatif dan Kritis serta Disposisi Matematik Siswa SMP dalam Pembelajaran Kontekstual dengan Model Coopeartive Learning. Tesis STKIP Siliwangi Bandung : Tidak dipublikasikan.

Sunendar, A. (2016). Mengembangkan Diposisi Matematik melalui Model Pembelajaran Kontekstual. Jurnal THEOREMS (The Original Researchof Mathematics, 1 (1), 1-9.

Yonandi (2010).Meningkatkan kemampuan komunikasi dan Pemecahan Masalah Matematik melalui Pembelajaran Kontekstual Berbantuan Komputer pada Siswa SMA. Disertasi. Bandung: Universitas Pendidikan Indo 
